Class, State, and dependency in the European semi-periphery:

Gábor Scheiring (2020) The Retreat of Liberal Democracy: Authoritarian Capitalism and the Accumulative State in Hungary. New York, Palgrave Macmillan. xxvii, 367 pages.

DDI: 10.17356/ieejsp..77i..866

Gábor Scheiring has written an extremely thoughtful and provocative book on the death of Hungarian democracy, introducing many new aspects. Rarely do we find such a wellthought-out, scrupulous, and well-structured work about Hungarian politics, in which the theoretical and empirical parts build on each other in supporting the key statements of the book. In line with the dominant position of political science in Hungary and internationally, the author considers the Orbán regime to be a competitive or elective dictatorship, and consequently places it among hybrid regimes (cf. Levitsky \& Way, 2010; Schedler, 2005; 2015). This book, however, is not so much about the nature of the already fully fledged Orbán regime (see, for example, Scheiring \& Szombati, 2020) than about the reasons behind its emergence.

The author claims that the primary reason for the historic failure of the fragile Hungarian democracy, emerging in the wake of the change of the regime, is market fundamentalism, which came to dominate Eastern Europe after 1989 (cf. Soros, 1998). Its principles and key concepts, including privatization, deregulation, shock therapy, financial and trade liberalization, macroeconomic stabilization and market society were accepted by the Hungarian parties. Thus, the electorate belonging to social groups below the middle-class were unable to find a political alternative in the 1990s, which would have credibly represented the principle of equality in addition to freedom. Eventually, these voters, having lost their patience, lined up alongside the right-wing and far-right forces operating on the exclusionary notion of 'nation'. Scheiring points out that for significant groups of voters, the shift essentially implied the replacement of the concept of 'class' with the concept of 'nation', without a change in the substance of their basic attitudes initially. Workers, who in the early 2000s were not yet receptive to ethnicist ideology (cf. Szalai, 2004), had mostly espoused it by the end of the decade. The 2010 political turn put an end to the era of liberal democracy and voters gave a green light to the rise of an illiberal, competitive dictatorship (initially labelled as a majoritarian democracy).

Because Scheiring sometimes calls the period of 1990-2010 a democracy and other times he dubs it as a 'simulated democracy', it is not always clear exactly what he means. In my opinion, the author describes an elite-driven, institution-centred democracy, which re- 
mained one-sided over the years because active social participation could not gain strength. Consequently, many identified the concept of democracy with the multi-party system only. In contrast with such democratic deficit, however, the concept of simulation presupposes intentionality on the part of political actors, and it would be an exaggeration to extend it to the entirety of the above-mentioned twenty years. My impression is that it is more likely that that the co-emergence of capitalism and democracy was a process laden with serious contradictions. The fact that democracies survived in capitalist systems only does not imply that a newly established capitalism automatically leads to democracy. Nor is it certain that the nascent market economy will automatically consolidate a semi-peripheral democracy which had no historical antecedents, and which emerged as result of an international domino effect.

The term 'simulated democracy' is more fitting for the period starting from 2010, when the regime - in a manner that Prime Minister Orbán himself called a 'peacock dance' elevated the double speech to the rank of official politics (on the Orbán regime see Magyar \& Vásárhelyi, 2017; Kovács \& Trencsényi, 2020). The defining moments of the period included the unilateral constitutional process (2011), the fourth amendment of the Fundamental Law, which shattered the rule of law (2013), free but unclean elections, and the proclamation of 'illiberal democracy' (2014). The exaggeration and propagandistic reinterpretation of the dangers posed by the wave of refugees (2015) and a referendum serving the interests of the ruling party (2016) fit into this list as well. As illiberal democracy, despite its misleading name, is not a democracy but a hybrid regime (cf. Bozóki \& Hegedüs, 2018a), by adopting it the Hungarian Prime Minister declared his break with the Westernstyle democratic system that has existed in Hungary since the change of regime. A typical communication strategy of a hybrid regime is double talk, which has appeared in both the domestic and international politics of political leaders in power. After Fidesz's victory in the 2018 'semi-free' elections, peacock dancing was less and less needed, although electoral autocracy persisted until the adoption of the 2020 emergency law (Scheppele, 2020).

According to Scheiring, the key social factor behind the emergence of the Orbán regime was the parallel revolt of the working class and the national bourgeoisie against growing inequality and insecurity engendered by the neoliberal competition state. I believe the author is right in that for a considerable part of the working class it was indeed a revolt: the fact that beside Fidesz, the far-right Jobbik also became visibly stronger, attests to that. What began was not some 'rubbing shoulders with' the future authority, but a search for new, radical political agents who defined themselves in opposition to the policies of the left-liberal coalition government.

In the case of national capitalists, however, this opposition was by no means so sharp, nor was changing sides. In their case, it was not so much a rebellion or ideological identification, but rather a flexible adaptation to the new political environment created by Fidesz, which by 2010 had risen to power. Those Hungarian capitalists who were unable to compete with multinational companies that paid higher wages, created better working conditions, and even tolerated the operation of trade unions sought and found favour in the protectionist nation-state in exchange for their political loyalty. This is evidenced by the fact that 'right-wing capitalists', as Scheiring calls them, almost unanimously opted for Fidesz, rather than Jobbik, from the two right-wing parties available to them. Of the rising 
right-wing forces, they turned towards the only party that had a chance to come to power (and which did come to power eventually) because that is what promised them regulatory benefits and state benefits.

Although The Retreat of Liberal Democracy is first and foremost a critical political economic analysis, Gábor Scheiring successfully proves that he is also well-versed in the international literature of political sociology and political science understood in a narrow sense. He analyses dominant explanations about the decline of liberal democracy, highlighting interpretations related to the violation of liberal norms by political elites, cultural determinism, the failure of modernization and those referring to the impacts of the world system. Elitist explanations focusing on political voluntarism can be rightfully criticized both by proponents of both modernization theory and world-systems theory. Institutional theory or elite theory, however, which examine the role of political agents, provide better answers to country-specific questions requiring a case study than the overly general world-systems theory.

\section{The concept of class}

Key concepts in the book include class, the state and dependency. One of the innovations of Gábor Scheiring's book is that it boldly rehabilitates class analysis and emphasizes that the concept of class has kept its raison d'être even in the bubble societies of the 21st century, amid the unstable political environment and individualized mass society. Scheiring insists that the concept introduced by Marx, which was laid to rest several times in the second half of the 20th century, remains timely, even if not in the same way as Marx had envisaged it. According to the author's definition, all those individuals who sell their knowledge or labour belong to the working class, but he also stresses that societies today cannot be divided into two classes, workers and capitalists only.

Scheiring differentiates between skilled and unskilled workers when it comes to the working class, and between transnational and national capitalists when writing about the capitalist class. By the term 'working class' in the 'narrower sense', he implies those who are forced to sell their own labour in order to make a living and do not have a significant amount of economic, relationship or cultural capital. However, the author does not provide a definition for the working class in the broader sense. For a moment it seems that he includes technocracy here as well, but he later claims that he regards managers and the credentialled as a new, cosmopolitan, technocratic class separate from labour, which is ultimately closer to capitalists than to the working class. Then, the author also accepts the thesis of the relative autonomy of the state, based on which he concludes that the operators of state power constitute the political class as an independent actor. According to Gábor Scheiring, there are thus four classes in contemporary global capitalism: the working class, the capitalist class, the technocratic class and the political class.

In addition to the ownership of labour and profit, convertible knowledge and state power also become class-forming factors. The class theory followed by the author thus does not necessarily assume given social classes; symbols of the cultural field and political institutions play a role in the lived class positions just as much as the economic division of labour and production method existing in the given historical and geographical context. Moreover, classes do not necessarily have to manifest themselves in everyday life, it is

INTERSECTIONS. EAST EUROPEAN JOURNAL OF SOCIETY AND POLITICS, 7(1): 161-176. 
enough if they come to the surface at certain crisis situations that represent certain critical junctures.

What follows from this is that the author uses a rather loose concept of class, in which economic structures represent only one variable in class formation. Classes appear primarily as 'classes in themselves' (Marx), or as 'status groups' (Weber), which become dynamic only at times of intense social conflicts and organize into 'classes for themselves' or into 'social classes' (Weber). The author further expands the scope of class theory, a step that Marx himself would disagree with, but Bakunin, Dilas, Szelényi and Gouldner would not. The author thus accepts the theory of the 'new class' by interpreting the new, transnational, cosmopolitan, credentialled groups as a class in addition to the traditional antagonistic classes. Finally, in addition to technocracy, Scheiring also introduces the concept of political class in the analysis, thus expanding his own class analysis with theoretical approaches that reflect not only the Marxist tradition represented by Gramsci and Poulantzas, but also the influence of Foucault and Bourdieu.

The author thus seeks to remain true to the research agenda of rehabilitating class analysis by interpreting the concept of class extremely broadly, while also staying open to post-structuralist approaches. He analyses the impact of structure and acting agents together, and attributes class-forming power to structural factors, such as political institutions and the cultural field. The author, however, reaches a slippery ground here because the concepts of 'field' and 'habitus' were developed by Bourdieu precisely as an alternative to class analysis divided into structures and actors.

Scheiring's class analysis stays within the framework of immanent system criticism: his critical stance is not formulated as anti-capitalist, but as a left-wing position within the system. Marx remains an important source for him, but not so much in connection with content as with methodology. He rejects the ideological interpretation of the proletariat as a revolutionary agent and focuses on a sociological approach towards workers. For example, when he discusses the compatibility of capitalism and democracy, he further elaborates the works of Adam Przeworski, written in the 1980s. According to Przeworski's thesis, antagonistic opposition between capitalists and workers is not always present, on the contrary, they are able to make lasting compromises with each other despite their conflicting interests. What unfolds before our eyes through the concepts of capitalist rule, the rule of law, the embedded party system and the protection of collective interests is a social democratic strategy.

In his research on the history of social democracy, Przeworski concluded that democratic welfare capitalism was a more attractive option for workers than a socialist revolution with uncertain outcomes (Przeworski, 1985; Przeworski \& Sprague, 1986). As long as the capitalist state can guarantee them the possibility of material prosperity and democracy, workers will choose capitalism over revolution. Democracy is the result of a class compromise concluded by representatives of economically and politically well-organized classes. The social democratic, Christian democratic, and social-liberal systems after World War II were built on the model of democratic capitalism maintained by welfare states. This was perhaps because the Soviet-type regime, referencing Marx, existed until 1989-91 as an alternative to Western capitalist democracies. Although this system was neither culturally attractive nor economically successful, in a military sense it posed a serious threat to humanity for a long time.

INTERSECTIONS. EAST EUROPEAN JOURNAL OF SOCIETY AND POLITICS, 7(1): 161-176. 
What also becomes clear from Gábor Scheiring's book is that classical social democracy, which builds on class compromise, was not an available alternative for the Central and Eastern European countries that were exposed to the shock of post-communist transformation. The new democratic, post-communist elite that came to power in the 1990s believed in the primacy of market coordination; some of this elite even absolutized the societal role of market logic. The author calls them market fundamentalists.

In these countries, the existing left pursued a policy of liberalization, marketisation, and cultural cosmopolitanism within the framework of the modernization paradigm, while the existing right promoted the control of social subsystems by the nation state. The left was both economically and culturally liberal, while the right was anti-liberal in both respects. All this preceded the emergence of social polarization beyond democratic fault lines. Scheiring's analysis convincingly points to the deepening material and cultural gap between Hungarian workers and the economic elite.

The Eastern European societies undergoing transformation were not completely alone in this regard, because by the time of the 2008 financial crisis, the class compromise, which had maintained democracy for a long time, had begun to disintegrate in Western countries as well. Moreover, capitalism, which was left without competition, also underwent a paradigm shift in the decades following the Cold War. Class analysis was made more difficult by the fact that in global capitalism, which has replaced local welfare capitalist systems, the welfare state was replaced by 'market society', while democracy was replaced by 'post-democracy' and an organized working class was replaced by a fragmented and unstable precariat (Crouch, 2004). The livelihood gap between the global elite and workers expanded spectacularly and the culture of inequality was normalized.

Scheiring thinks it is important to bring class analysis back into the Hungarian social science discourse, despite - or perhaps precisely because of - experiences related to Eastern European 'wild capitalism' following the collapse of state socialist class politics. His inspiration to do so may have been the constructivist approach suggesting the existence of all social phenomena which concepts are created for. The author also refers to a working class and a capitalist class in 'peacetime' as well, when organization into a class is politically invisible. It would have been worthwhile to discuss the role of the other two classes he refers to, the technocratic and the political class, in maintaining the regime. If we accept the plausible statement that every democracy is the result of a class compromise, in future research it will be worth examining whether such a compromise is made by classconscious actors or by actors in a similar class position who randomly drift near power. It can be hypothesized that the parties reach a class compromise at critical historical moments, typically in crisis situations, i.e. when the class consciousness of actors belonging to a similar class position is temporarily dynamized by the crisis.

\section{The concept of state}

Another notable innovation of the book is the description of the state's transformation. Comparing the periods during and after the change of the regime, the author differentiates between three stages, assigning a different type of state to each of them. The first is the vestigial welfare state, a legacy of state socialism; the second is the competition state that emerged during the 20 -year democratic period; the third is the accumulative state that 
gained ground in the post-democratic Orbán era. According to Scheiring, what emerged during the era of state socialism was not a 'premature welfare state', as described by János Kornai (Kornai, 1989; 1993), but a 'vestigial welfare state' which he considers in more positive terms. Thus, the problem with the welfare services provided by the state in the socialist era was not that they came too early, but that they covered only a few areas. Here it would have been an attractive intellectual challenge for Scheiring to critically analyse Kornai's concept in more detail, but he did not take this opportunity - presumably because the primary subject of his book was not an analysis of the pre-1989 socialist state.

In the period following the change of the regime, the vestigial welfare state was gradually replaced by a pro-market (and in some cases neoliberal) 'competition state'. The competition state (for its definition, see Drahokoupil, 2008) considered as its main task to ensure marketisation and macroeconomic stabilization, to create an attractive investment environment, i.e. the successful adaptation of capitalism, while it sought to pacify those who dropped out of the competition through early retirement and unemployment benefits. The latter led to a significant decline in the share of the employed within the population, so the competition state, paradoxically, carried an increasing proportion of dependents on its back. This contradiction allows us to conclude that the competition state was not really neoliberal, as it continued to offer certain achievements of state socialism in order to maintain social peace for the losers in the competition. Here, perhaps it would have made sense to place more emphasis on the responsibility of the economic and political elite in the years immediately following the change of the regime for 'managing' privatisation, not only in an anti-social but also in a criminal respect. The competition state was dominant, but not exclusive, because some structures of the vestigial welfare state persisted throughout the entire era, which reduced social tensions pertinent to the transition to capitalism. For example, the Medgyessy government sought to build on these structures and expectations when it announced its social democratic programme of 'welfare regime change' in 2002.

However, by the end of the second decade after the regime change, it became clear that the competition state was no longer able to enhance the country's competitiveness. What was still successful in the decade between 1995 to 2005 gradually failed in the years that followed. The global economic crisis of 2008 exposed the need for a change in economic policy. However, the elite of the competition state reacted to the crisis in the old way: it continued to think in terms of financial and economic austerity. All this led to a rapid loss of political credit and a radical change in political demand.

Scheiring calls the state that emerged after 2010 an 'accumulative state' (see Wolfe, 1977), a notion that is not frequently used in Hungary but is well-known in international scholarship. In this paradigm, the function of the state is to boost economic development through massively and excessively rewarding certain national capitalist groups, relying on domestic resources. The question, however, is to what extent is the concept of the accumulative state applicable to a context where political entrepreneurs occupying the state from within redistribute public funds to their henchmen and to capitalists connected to them on the basis of political loyalty, while undermining the rule of law? Such a state indulges some but plunders many others: it systematically rewards a relatively narrow circle - provided the state has any 'relative autonomy' and is separable from this circle at all -, while it applies a social Darwinist workfare policy with regard to those lagging behind. Its survival was made possible not only by the world economic conjuncture of the 2010s,

INTERSECTIONS. EAST EUROPEAN JOURNAL OF SOCIETY AND POLITICS, 7(1): 161-176. 
but also by the state control of the public media, the polarization of society, its xenophobic and ethnicist politics, a permanent war rhetoric, the personal charisma of the head of government and the faltering - structurally restrictive, but also occasionally supportive policy of the European Union (Bozóki \& Hegedűs, 2018b; Tamás, 2020).

Scheiring's conduct is fair when he mentions approaches that contradict his own position - in addition to János Kornai's theory, he cites, for instance, Bálint Magyar's concept of the 'mafia state' (Magyar, 2015; 2018) - but he does not challenge them substantially. He calls the latter a neo-utilitarian approach. At one point, he misunderstands the thesis of the mafia state, discussing it under 'crony capitalism'. In crony capitalism, the 'cronies' taking part in mutual sharing are more or less equal. The essence of the mafia state, however, is centralized, vertical, personalised power. Its practitioners cannot be characterized by reciprocity or horizontal relations but rather by the system of relations of the 'adopted political family', governed by a single person, the 'head of the family', who - as a political boss - grants economic and political power, influence and prestige from above, who is uncritically accepted by his followers. In contrast to crony capitalism, every person holding a position in the mafia state is an actor who has been bribed by the 'head of the family'.

The post-communist mafia state is a personalized system; it is not based on existing formal institutions but on the informal power of the leader and the resulting arbitrary decisions. As a consequence, it is irrelevant whether the head of the state, the chief prosecutor, the commissioner of fundamental rights, the constitutional court or the media council are 'independent' actors on paper, because in practice they are governed by the regime's namesake. In this structure, central decisions may also be aimed at rearranging ownership relations, for instance, according to the method of transit nationalization. The 'predatory' nature of the state is based on the chief's efforts to meet the needs of his clientele because the system cannot be sustained without their support. Nevertheless, the thesis of the mafia state is a partial theory because it focuses on the functioning of the state and does not in itself provide an answer to the relationship between the state and society, nor does it analyse the system's legitimacy or society's innermost shifts. The latter are better addressed by theories drawing on path-dependency, i.e. research on re-feudalisation, culture and value systems.

Both nationalization and re-privatization can be observed in the Orbán regime but ultimately it is not important because boundaries are blurred between private and public property, as well as between the state, the party and the leader's clique. The common set of the latter is what could be called a 'political family'. The concept of the accumulative state may be problematic because the head of government treats the country's assets essentially as his own, which makes the system sultanistic (or in other approaches: neopatrimonial, neoprebendal) (Csillag \& Szelényi, 2015). Public accumulation is exploitative in that it channels resources away from the low-wage earners and also sets public targets based on whether these resources can be reallocated to the accumulating clique.

The author distinguishes between two phases of the accumulative state. The first phase took place in the end of the 18th century, the beginning of the 19th century, when the old order was able to retain its influence as a result of a compromise between the nobility and the bourgeoisie; in return, the state that was under its control ensured the capital accumulation of the bourgeoisie. This 'pre-democratic' state was not open to integrating the working class into the system - in fact, it was specifically seeking to exclude it - be-

INTERSECTIONS. EAST EUROPEAN JOURNAL OF SOCIETY AND POLITICS, 7(1): 161-176. 
cause its primary goal was to gain domestic and international markets for the bourgeoisie through state intervention. At this point, Scheiring mentions the American railroad construction companies in the Wild West (Central Pacific Railroad, Union Pacific Railroad) and the East India Company affiliated with the British Parliament, citing them as classic American and English examples of the accumulative state's beneficiaries. According to the author, at least in the English case, there were two independent actors: the rising bourgeoisie and the old, aristocratic order, which compromised with each other and embarked on great, collaborative projects.

Another phase (and also type) of the accumulative state, the author claims, can be observed in the semi-peripheral Hungarian economy, where the post-communist accumulative state not only mediates between national and international capital, but also serves the interests of both. Scheiring holds that the competition state focused only on introducing and operating capitalism, and thereby came under the influence of transnational capital. By contrast, the accumulative state, by marginalizing the working class, found an ally in national capital vis-à-vis transnational capital and tried to represent the interests of the former to counterweight the latter. This is possible because the state, as a political class, simultaneously represents its own class interests and seeks to exclude both the political opposition and the subaltern. Thus, while the competition state was able to prevail within the framework of democracy, the accumulative state is forced to break with democracy, because otherwise it would not be able to survive.

Thus, the accumulative state is not compatible with democracy. However, while the early accumulative state of the core countries was based on a compromise of two classes, the Hungarian accumulative state of the semi-peripheral post-communist region is described as a threefold alliance (political class, transnational capital, national capital). This is, however, more similar to the model described by the new, South American dependency theories than to the old development strategies in England or North America. In today's semi-peripheral authoritarian system, the political class favours national capitalists, while subordinating them and expecting unconditional political loyalty from them. The author claims that the power bloc is engaging in an authoritarian exercise of power that combines institutional authoritarianism and authoritarian populism to stabilize the new accumulation regime. Companies and their leaders may be catapulted to the top in no time and then go down the drain at the will of the state just as quickly. In the Orbán regime, we cannot talk of a compromise concluded between the national capitalist class and the political class as independent actors, only about the political submission of the capitalist class. It is a capitalism in which the fate of capitalists is in systemic dependence on their political loyalty.

Therefore, finding analogies between these two, temporally distant 'accumulative states' seems to be too adventurous an enterprise. The existence of relevant examples from recent centuries about the accumulative state facilitating the prosperity of some capitalist companies does not mean that state intervention in the given countries was systemic. It takes a great amount of imagination to consider the East India Society, founded by James Lancaster and supported by political circles in London, and the Hungarian corporate empire of Lőrinc Mészáros in the same paradigm, as analogous examples. While the former was involved in global international competition in the Indian Ocean and the Bay of Bengal for several centuries, the latter has a history as a company manager of barely ten years

INTERSECTIONS. EAST EUROPEAN JOURNAL OF SOCIETY AND POLITICS, 7(1): 161-176. 
and does not extend beyond some small states in the Balkans. The two corporate empires - despite all their differences not detailed here - are undoubtedly similar in that they performed both political and economic functions. However, while the East India Company was subject to the British crown only in political matters but was given a free hand in its economic activities, in the case of the Mészáros corporate group the strings of political and economic loyalty cannot be untangled.

It would be extremely exciting if, besides such extremely different examples which are relatively easy to question, Scheiring looked at Hungary's neighbours as well. I would be curious to know if the author would use the context of the accumulative state to describe the corrupt system of Meciar's Slovakia, built on the secret service and the police, or the paramilitary, gangster-capitalist state of Milosevic's Serbia, or even the operation of the Polish authoritarian state today. It is not entirely clear from the analysis to what extent the author considers the Hungarian accumulative state to be unique in the region, where each country embarked on building a market economy from a similar 'starting position' in 1990.

Therefore, the problem with applying the concept of the accumulative state in the Hungarian context is not that it is 'too friendly' with the Orbán regime but that it carries out conceptual stretching, i.e. an over-expansion of the scope of the concept during the analysis. In a comparative exercise covering two hundred years, the nature and number of classes and the real content of their activities can no longer be matched against each other in such an obvious way as the author assumes, therefore the problem is methodological in nature.

\section{Dependency theories}

The third cornerstone of the book is dependency theory. The author defines it in contrast to modernisation theory; rightfully so, since dependency theory emerged in response to the one-sidedness of the latter. However, it seems a bit of overstretching to call the idea of modernization liberal. It was liberal insofar as the post-World War II era can be considered liberal. In the 1950s and 1960s, at the time when the two world systems were competing and coexisting peacefully, modernization theory was not simply a liberal theory, but a developmental paradigm accepted by many political actors and political scientists of different ideological orientations from Khrushchev to Huntington. For a long time, the main tenets of modernization theory were shared by liberals, conservatives, socialists alike, and even by nationalists in emerging countries. Following sharp criticism in the 1970s, the theory's renewal was inevitable, then it resurfaced in new waves from the 1980s onwards. Legitimate criticisms of old modernization theories (too abstract, rejects alternative paths, assumes linear development, absolutizes the Western development trajectory, adheres to the nation-state framework as a unit of analysis, etc.) were no longer valid for new modernization theories.

Dependency theories underwent such renewal as well. The old dependency theory, associated with André Gunder Frank, saw dependence as a historical determination that could not be changed through traditional economic policy, and therefore sought to develop a development strategy that radically breaks with dependence (Frank, 1966). By contrast, proponents of new dependency theories that surfaced starting from the mid-1970s realized

INTERSECTIONS. EAST EUROPEAN JOURNAL OF SOCIETY AND POLITICS, 7(1): 161-176. 
that dependence in world economy was a condition that the revolutionary path would not only fail to remedy but would exacerbate instead. However, dependent development does not only engender disadvantages, but, in the case of a good development strategy, it may also present benefits as well. In his book, Gábor Scheiring sometimes contrasts new dependency theories with old modernization theories. New dependency theories are much more sophisticated than old modernization theories, but when compared with the new ones, this no longer holds. The author's position is thus critical of the system, but not anti-system: he does not rely on revolutionary, old dependency theories related to Frank, which consider dependence $a b$ ovo as a trap, but - following Cardoso, Faletto and Peter Evans - he draws on analyses that interpret dependence as a new opportunity for the development model (Cardoso \& Faletto, 1979; Evans, 1979). The latter no longer leads to the conclusion that a socialist revolution is in order, but to the development of a left-wing social democratic programme within the framework of capitalism.

The Latin American examples are often illuminating regarding the post-2010 Hungarian political system, especially in understanding its international embeddedness. One such example may be the concept of the bureaucratic authoritarian state (BA) developed by Guillermo O'Donnell, which he used to describe the economic policies of the Argentinian dictatorship of the 1970s (O'Donnell, 1988). The characteristic of the BA state was that it consciously restricted democracy and workers' rights in order to boost economic competitiveness, and that it sought to politically marginalize the salaried population. The author does not analyse this approach, although it is very similar to how he describes the functioning of the Hungarian accumulative state: If accumulation were not the essence of the power compromise, then there would be no need to neutralize, i.e. to hamper the organization of the dissent of those who are disadvantaged by accumulation. The seemingly neutral term, 'accumulation', in fact denotes an aggressive intervention, which implies the reallocation of goods, including the arbitrary rearrangement of ownership relations.

The new dependency theories examine economic development in the triad of multinational capital, the national bourgeoisie, and the state bureaucracy, and analyse the effects of possible coalition configurations among the three actors. The power triangle described by Peter Evans is based on the interplay and changing relationships between transnational capital, local capital, and the 'state bourgeoisie' (i.e. the 'entrepreneurial faction' of the state apparatus) (Evans, 1979; 1989). Consequently, based on the alternation of power cycles, dominant politics may be populist or neoliberal, but the system does not have to be tied to a single person. The Orbán regime is similar to the personalist regimes of Latin American countries but differs from others.

Sometimes it seems as if the author's goal, beyond the analysis of the Hungarian case, were to carry out a comprehensive critique of the liberal world order. This is indicated by the fact that he is much more critical of the proponents of modernization theory than of the proponents of dependency or world-systems theories which emerged in opposition to the former. This is so even though world-systems theory is methodologically more difficult (or not at all possible) to apply to explaining the rapid changes taking place in a single country, because its proponents explain those by the shifts in the world system. Thus, cause and effect become interchangeable: a shift in the world system may be both a cause and a consequence in the explanation of a phenomenon. This way theoretical conclusions remain tautological (cf. Wilkin, 2016). As the author is also aware, the world-systems theory

INTERSECTIONS. EAST EUROPEAN JOURNAL OF SOCIETY AND POLITICS, 7(1): 161-176. 
cannot give an adequate answer to the question why democracy collapsed in Hungary and why it did not in Slovenia, Romania or Slovakia -, as it applies large units of analysis and longer historical perspectives.

There is no such danger when it comes to the analysis of international economic and political dependencies, on the contrary: the research allows us to explore immensely diverse networks which vary case-by-case. For example, the way the leader of a postdemocratic country in the European periphery is trying to expand its international elbow room and how he is using the country's EU membership - in a utilitarian way, regarding it as a bargaining chip - in his politics domestically, in the Balkans, and in relation to the 'Eastern opening'. Dependency theory has come a long way in the last fifty years as it has evolved from a peripheral, Third World-focused, revolutionary Marxist theory into a dominant development theory paradigm through the emergence of globalization, the multipolar world order, and networks of interdependence.

\section{The empirical analysis}

The virtues of Gábor Scheiring's book include problem sensitivity, an interdisciplinary approach and methodological pluralism, which allow him to reach not only theoretical but also empirical conclusions. In addition to political economic research, he also carried out empirical sociological research, exploring the operation of the system. Although in this review I focused primarily on the theoretical foundations of the book, I must mention the elegance with which the author applies his theoretical questions in empirical research. This is important because he makes it clear that he considers both theory building and the empirical exploration of reality to be important for scientific inquiry. He is aware that reality cannot disappear in theory's shiny world because, as the Hungarian poet, Mihály Vörösmarty wrote, 'He who longs to see / looks not upon the sun. ${ }^{11}$ In this spirit, Scheiring places great emphasis on the empirical chapters as well, focusing on the economic elite, the working class and the practical operation of the accumulative state, as well as other sub-themes relevant for the main point of the book.

Using the metaphor of the revolving door, the author describes the careers of some members of the economic elite. A common feature of these careers is that in the decades following the regime change, members of the elite showed up behind the steering wheels of state administration as well. The author reviews where they came from, what school they graduated from, where they worked, how these actors switched between the public and private sectors, and to what extent were they active in the world of national and international capital. The research revealed that while 'left-wing' finance ministers more likely came from the banking sector, 'right-wingers' were less typically from the practical domains than from academia. Both groups include radical proponents of marketization and more moderate modernizers, so abstract ideological orientation makes less sense in economic policy. Scheiring provides an outline of their stories, focusing mainly on wellknown characters, rather than carrying out a systematic analysis, but the connections exposed are nevertheless revealing. In this form, the first results of the research suggest a further research hypothesis, conceived in the Gramscian spirit, that the attitudes and decisions of economic leaders can be explained based on their life paths. This chapter can

\footnotetext{
Mihály Vörösmarty: To A Dreamer. (Own translation.)
} 
also be read as a stand-alone case study, but it would be worthwhile to elaborate it in detail later in a separate book.

Scheiring's focus, however, is not limited to the elite. In addition to the positional analysis of the various groups of capitalists, which also shows their proximity to central political power, he is keen to give voice to the working class. Interviews with workers from former mining towns shed light on the dramatic changes in the situation of the poorer segments of the working class. Quotations from the, sometimes shocking, testimonies underline that workers, understandably, hanker for the Kádár regime, which allowed them, when they were young and strong, to work in communities with a collective spirit and a strong ethos of equality. Strong family and neighbourhood ties and the internal solidarity of socialist brigades remained a positive example for them even when the broader, more distant framework of their lives was determined by political repression. However, Durkheimian 'mechanical solidarity' between workers (Durkheim, 1984) may have been so strong because it was defensive in nature (Ágh, 1987). Micro-level solidarity communities of social self-defence were designed to fend off macro-level mistrust, i.e. the complete absence of 'organic solidarity' known from democracies. They could not trust anyone but each other.

The true merit of the empirical chapters is that they bring the key statements of the book close to the reader, which the author substantiates using quantitative and statistical methods as well. This is all the more necessary because the interviews themselves are inevitably illustrative in nature and serve to prove and illustrate the story at the same time. After reading the interviews the reader may feel that something is missing, because they unanimously convey a clear rejection of the new system after 1989, dissenting voices do not appear. Respondents assess the new economic situation after the change of regime from the perspective of losers. The research presented by the author tends to suggest that the Kádár regime, in the case of an imaginary survival, would have been better for the salaried people, promising better perspectives for their children than the new democracy that emerged after the fall of the system. However, the author's personal life story, which he briefly shares with readers in the preface, shows that the regime change also provided incredible opportunities for talented youth from non-middle-class families as well. Posterity has an ambivalent picture of the Kádár era, representing the system almost simultaneously as a 'workers' paradise' and the rule of 'labour-buying' cadre bureaucracy. The interviews in the book, however, emphasize the first interpretation.

The rhetoric of the post-2010 system suggests that after the era of 'neoliberal rule,' the government is now set to protect the Hungarian people: the national bourgeoisie has formed an alliance with the state bureaucracy against multinational corporations to protect domestic workers from exploitation. Populism, however, is only meant to cover up what connects the Orbán regime to the democratic era. In reality, Orbán's accumulative state this time through 'strategic agreements' and favouring certain key sectors - continues to support the raising of foreign capital. It is perhaps not accidental, given that Hungarian workers are ensured better working conditions at multinational corporations, wages are higher, and sports and infrastructural subsidies are possible as well, which contribute to the legitimacy of the system. 'Don't pay attention to what I say, pay attention to one thing only: what I do.' - that is how Orbán summed up the key to his future political system before he came to power (Orbán, 2011).

INTERSECTIONS. EAST EUROPEAN JOURNAL OF SOCIETY AND POLITICS, 7(1): 161-176. 
While the Orbán regime supports its own clientele, the upper-middle class, the church and spectator sports, a considerable part of the state revenue required for this is generated by car manufacturing factories and multinational companies which set up their sites in Hungary. The rest comes from European taxpayers in the form of EU subsidies, and a smaller portion is transferred home by Hungarians working abroad. A large part of the Hungarian working class works as blue-collar entrepreneurs, nannies or social care workers in Western European countries. The working class - supposing we accept this disputed term as valid - has been voting with its feet as well since 2010: you may choose between 'exit' and 'loyalty' because you do not have the opportunity to effectively protest (cf. Hirschman, 1970).

Finally, before the reader starts blaming workers for the death of Hungarian democracy, the author emphasizes that the revolt of the working class did not entitle Fidesz to dismantle democracy. Workers' revolt was not against something, but for something: not against democracy, but for the greater security promised. The author claims that workers may have been anti-liberal, but they were not anti-democratic. However, the validity of this statement is questioned precisely by the workers' interviews conducted by the author, because interviewees considered Kádár's dictatorship to be better than the subsequent democracy. Could it not be then that they authorized Fidesz to dismantle democracy in the hope of new job opportunities ensuring existential security?

Maybe they had a different understanding of the concept of democracy. They understood democracy as their own narrower, familial-professional communities, collegial solidarity communities, and were uninterested in large structures, the broader horizon, or the regime itself. They believed that these communities disintegrated after 1989. Contrary to the optimistic expectations, workers did not see the development of capitalist democracy as a positive civilizational turn (cf. Sztompka, 1995), but as a process of dehumanization. On the one hand, they projected the concept of democracy back into the past, into the local solidarity communities that once existed; on the other hand, they were increasingly hopeful with regard to political forces that were drumming the primacy of ethnic identity. They were not seeking democracy as citizens but as dispossessed workers, and they rightly believed that events in the cloud regions of politics could no longer worsen their micro-world; maintaining a democratic system at the national level was not their job, they might have thought, so they had nothing to lose with their revolt.

Scheiring's book is characterized by comprehensive knowledge of the scholarly literature, sophisticated analyses, and methodological pluralism. He uses both quantitative and qualitative approaches and is successful in balancing theory and empirical work. His is an unusual book: almost all of his key statements might provoke debate, but eventually the reader concludes that in light of the big picture, Scheiring is right.

ANDRÁs BozóKI

(Central European University)

INTERSECTIONS. EAST EUROPEAN JOURNAL OF SOCIETY AND POLITICS, 7(1): 161-176. 


\section{References}

Ágh, A. (1987). A védekező társadalom (Defence society). Magyar Tudomány, 94(1), 1-14.

Block, F. (n. d.). Reframing the battle: Market fundamentalism vs. moral economy. Longview Institute. https://www.longviewinstitute.org/projects/moral/sorcerersapprentice/

Bozóki, A. \& Hegedűs, D. (2018a). Democracy, dictatorship and hybrid regimes: Concepts and approaches. In Solska, M., Bieber, F., \& Taleski, D. (Eds.), Illiberal and authoritarian tendencies in Central, Southeastern and Eastern Europe (pp. 21-49). Peter Lang. https://doi.org/10.3726/b10585

Bozóki, A. \& Hegedűs, D. (2018b). An externally constrained hybrid regime: Hungary in the European Union. Democratization, 25(7), 1173-1189. https://doi.org/10.1080/1351 0347.2018.1455664

Cardoso, F. H. \& Faletto, E. (1979). Dependency and development in Latin America. University of California Press.

Crouch, C. (2004). Post-democracy. Polity Press. https://doi.org /10.1111/1467-923X.12210

Csillag, T. \& Szelényi, I. (2015). Drifting from liberal democracy: Traditionalist/neoconservative ideology of managed illiberal democratic capitalism in post-communist Europe. Intersections. East European fournal of Society and Politics, 1(1), 18-48. https://doi. org/10.17356/ieejsp.v1i1.28

Drahokoupil, J. (2008) The rise of the competition state in the Visegrád Four: Internationalization of the state as a local project. In Van Apeldoorn, B., et al. (Eds.) From Lisbon to Lisbon: Contradictions and limits of neoliberal European governments (pp. 187-208). Palgrave. https://doi.org/10.1057/9780230228757_10

Durkheim, É. (1984). The division of labor in society. The Free Press.

Evans, P. (1979). Dependent development: The alliance of multinational, state and local capital in Brazil. Princeton University Press.

Evans, P. (1989). Predatory, developmental and other apparatuses. Sociological Forum, 4(4), 561-587. https://doi.org/10.1007/BF01115064

Frank, A. G. (1966). The development of underdevelopment. Monthly Review Press.

Hirschman, A. O. (1970). Exit, voice, loyalty. Harvard University Press.

Kornai, J. (1989). Indulatos röpirat a gazdasági átmenet ügyében (A passionate pamphlet in the cause of Hungarian economic transition). HVG.

Kornai, J. (1993). A szocialista rendszer. Kritikai politikai gazdaságtan (The socialist system: Critical political economics). HVG.

INTERSECTIONS. EAST EUROPEAN JOURNAL OF SOCIETY AND POLITICS, 7(1): 161-176. 
Kovács, J. M. \& Trencsényi, B. (2020). Brave New Hungary: Mapping the System of National Cooperation. Lexington Books.

Levitsky, S. \& Way, L. A. (2010). Competitive authoritarianism: Hybrid regimes after the Cold War. Cambridge University Press.

Magyar, B. (2015). A magyar maffiaállam anatómiája (Anatomy of the Hungarian mafia state). Noran Libro.

Magyar, B. (2018). Towards a terminology for post-communist regimes. In Magyar, B. (Ed.), Stubborn structures: Reconceptualizing post-communist regimes (pp. 97-176). CEU Press.

Magyar, B. \& Vásárhelyi, J. (Eds.) (2017). Twenty-five sides of a post-communist mafia state. CEU Press.

O’Donnell, G. (1988). Bureaucratic authoritarianism: Argentina 1966-1973 in comparative perspective. University of California Press.

Orbán, V. (2011). Orbán a Wikileaksen: Ne arra figyeljenek, amit mondok, hanem arra, amit teszek (Orbán on Wikileaks: Do not listen to me, just look at what I am doing). Paraméter, 6 September. https://parameter.sk/rovat/kulfold/2011/09/06/orbanwikileaksen-ne-arra-figyeljenek-amit-mondok-hanem-arra-amit-teszek

Przeworski, A. (1985). Capitalism and social democracy. Cambridge University Press.

Przeworski, A. \& Sprague, J. (1986). Paper stones: A history of electoral socialism. University of Chicago Press.

Schedler, A. (Ed.) (2006). Electoral authoritarianism: The dynamics of unfree competition. Lynne Rienner.

Schedler, A. (2015). The politics of uncertainty: Sustaining and subverting electoral authoritarianism. Oxford University Press. https://doi.org/10.1093/acprof:oso/978019968032 0.001 .0001

Scheiring, G. (2020). The retreat of liberal democracy: Authoritarian capitalism and the accumulative state in Hungary. Palgrave Macmillan. https://doi.org/10.1007/978-3-03048752-2

Scheiring, G. \& Szombati, K. (2020). From neoliberal disembedding to authoritarian reembedding: The making of illiberal hegemony in Hungary. International Sociology, 35(6), 721-738. https://doi.org/10.1177/0268580920930591

Scheppele, K. L. (2020). Orbán’s emergency. Hungarian Spectrum, March 22. https://doi.org /10.17176/20200330-012828-0

Soros, G. (1998). The crisis of global capitalism. Public Affairs.

Szalai, E. (2004). Tulajdonviszonyok, társadalomszerkezet és munkásság (Property relations, social structure, and the working class). Kritika, 33(9), 2-6.

INTERSECTIONS. EAST EUROPEAN JOURNAL OF SOCIETY AND POLITICS, 7(1): 161-176. 
Sztompka, P.(1995). Cultural and civilizational change: The core of post-communist transition. In Grancelli, B. (Ed.), Social change and modernization: Lessons from Eastern Europe (pp. 235-248). De Gruyter.

Tamás, G. M. (2020). Szabadság és járvány (Freedom and epidemic). Mérce, 12 April. https://merce.hu/2020/04/12/tgm-szabadsag-es-jarvany/

Wilkin, P. (2016). Hungary's crisis of democracy: The road to serfdom. Lexington Books.

Wolfe, A. (1977). The limits of legitimacy: Political contradictions of contemporary capitalism. The Free Press.

INTERSECTIONS. EAST EUROPEAN JOURNAL OF SOCIETY AND POLITICS, 7(1): 161-176. 